\title{
The Library Technical Assistant
}

\author{
by Rosalind Campbell \\ Librarian \\ Caldwell Technical Institute
}

\begin{abstract}
This session this morning is a discussion of the Library Technical Assistant, her training, and her job and the various aspects of the program in which she was trained. The very fact that I was asked to be on the program is another indication that the library technical assistant has at last been recognized by the library profession, and hopefully that this emerging field is leading to a new level of library development and to a new era of librarianship.
\end{abstract}

To give you some idea of what changes have occurred, six years ago when we at Caldwell had the only program in the state of North Carolina, some of my friends and co-workers expressed the fear that these technicians or "sub-professionals" would be hired by libraries too poor to afford professional staff and that they would be "cheap substitutes" for librarians. They also were concerned that these people could not find employment. Some even suggested that we offer instead only a short term training session for clerks or aides.

You will remember in 1967, the whole concept of technical training for library technicians took a direct blast from Mr. Samuel Sass in an article in THE LIBRARY JOURNAL entitled "Instant Librarians." However, it was at the conference of ALA in San Francisco in that year, the one which featured manpower problems, that a positive and different approach was taken. At that meeting I heard discussions (some quite heated) and attended "brainstorming" sessions which brought together valuable information concerning the need for concerted action on various aspects of manpower needs for librarians. The stage was set there for the many developments which have taken place since.

1. An ad hoc committee on manpower problems was appointed by the president of ALA to evaluate and to plan for future action.

2. ALA (LED Division) published in 1968 a definition and a draft of guidelines for a LTA program called the "Deininger Report." Dorothy Deininger, Joleen Bock, Robert Booth, Frances Henne, Margaret Monroe, and Joseph Shubert served on the initial committee.

3. There also have been other events worthy of note:

a. Maryland School of Library Information Services Manpower Project, which was an assault on use of manpower in libraries, was undertaken.

b. New Standards for School Media Programs revised and transformed the traditional school library into a media center. 
c. School Library Manpower Project of the American Association of School Librarians was a re-evaluation of education for librarians.

d. Department of A-V Instruction produced the JIMS study.

e. Federal Library Service Committee - evaluated qualifications and position classification standards for federal library technicans.

In addition, there was the rapid emergence of LTA programs in Canada with the blessings and help of Canadian Library Association and the Ontario Library Association. The professionals in Canada were much quicker to accept the fact that the presence of a trained paraprofessional, or a LTA, as a member of the library team would enhance rather than detract from the professional status of the librarian.

The role of the librarian is changing and professional librarians are becoming more and more administrators rather than the traditional keeper of books. Now they are called upon to administer both library and audio-visual services, dial access systems or media labs, or television, radio, publications and other attendant services. Thus supportive services become increasingly essential. The professional librarians need to define both their own roles and the responsibilities of the paraprofessional and then stick to those definitions - "Don't do his job and don't ask him to do yours." In short, we now recognize that a properly trained library technical assistant can do nothing but up-grade the entire library profession.

In the last few years, patterns of consistency have developed in North Carolina and we are showing signs of developing good, sound programs in this state as well as elsewhere. Now we think of a manpower team composed of the professional, the trained paraprofessional, and a clerical staff working together for maxi- mum production and efficiency, and we know that we in North Carolina can provide training on the various levels that will do just that.

At the Fourth Annual Meeting of COLT (Council on Library Technology) of Palm Beach, Florida, in June 1970, Mrs. Elnoro Portteus, Directing Supervisor of School Libraries for Cleveland Public Schools and on the advisory board for the LTA pro. grams in the community colleges of Ohio, said: "Potentially, there is no doubt that the library technical assistants will be in demand and that their skills will be $r e^{-}$ fined in proportion. They do fill a unique place, distinctly different from the com petent school librarian."

Dr. Asheim states in his position paper in the ALA BULLETIN in 1968: "Much more serious a hurdle is the traditional self image of the professional librarian which will have to be altered so that change will be welcomed, new roles assimilated, and the pain of transistion minimized. ... The constant improvement of library service overall ... and not just the maintenance of library service at its present level . . must be the long-term objective of the profession. ... .'

In 1971, at the COLT workshop of Chicago and again at a workshop at Rutgers University, Dr. Asheim re-affirmed the ALA position in its Policy Statement which provides a criteria for the hiring of library personnel and the training pro grams for this supportive position. I cal your attention to this document, which was published last winter even though I am sure that you have read it - perhaps several times. This statement is the latest revision which delineates ALA's position concerning the various levels of employ; ment and staffing needs for all kinds of library positions.

These have been busy and exciting years. I have attended several COLT work shops and conferences plus many meetings 
of library groups - local, state and national. The Institute for LMTA Educators at Rutgers University headed by Dorothy Deininger was one of the most valuable and productive experiences of them all.

I would like now to review for a few moments our particular program at Caldwell Community College and Technical Institute and then we will move on to the LTA herself, her background and training.

In 1966 we launched the first librarytechnician training program in the state with only five students enrolled. Since that time, the program has changed its direction in order to meet the ever-changing requirements of expanding information and of media centers. Now called the librarymedia technical assistant program, its purpose is to provide necessary training in the procedures used by such centers so that students can become proficient in their work soon after employment.

Because materials are numerous and varied, the curriculum is based on a broad, rather than a narrowly specialized, background of information and on specialized skills needed to handle all kinds of media and equipment. The curriculum also introduces a variety of experiences, such as public and personal contacts, production and processing materials, descriptive cataloging and ordering, circulation procedures, maintenance and operation of audiovisual equipment, and the preparation of displays. Students who enroll at Caldwell for six quarters of study and practice receive an Associate of Applied Science coursework and practicum.

The liberal arts general-education courses make up approximately 50 percent of the curriculum so that a student can transfer to a four-year baccalaureate program should he so desire. The librarymedia content courses do not permit the student to transfer to library-science or audiovisual professional-degree programs, but they are quite helpful as background for students desiring to enter one of these professional fields. Should there arise a need for training technical assistants for special libraries, such as medical libraries, a few additional courses may be offered in place of some of the electives now listed.

Curriculum implementation at Caldwell required us to find solutions to more than the usual number of problems encountered in beginning a new program. First, the administrators of the program had to come to grips with the virtual nonexistence of textbooks and ready-to-use instructional materials designed for the library-media technical assistant. Because this was a new position in the field of information services, the absence of clearly-defined job descriptions and task-analysis surveys also made the recruiting of students and the development of course outlines somewhat difficult. Since that time, however, as I have already mentioned, the program has gained favor among the administrators of libraries and information and media centers, and it has attracted students of all ages and interests. The variety of tasks conducted in pleasant surroundings and the opportunity to work with people make this position very lively and satisfying.

An applicant for the program must have graduated from high school and should possess the personal attributes and interests necessary to work under the conditions imposed on him or her by the rigorous routines in a media center. Incidentally, all our graduates have been female, by chance, not by design.

The Library-media technical assistant program at Caldwell has been relatively inexpensive to operate. However, it would be more expensive if one were to provide a separate laboratory with a collection of catalogs, indexes, typewriters, projectors, and other equipment of basic importance to a media center.

The faculty members of such a program 
should have teaching backgrounds as well as professional preparation in the media field. The organization of a community advisory committee, consisting of media specialists, professional librarians, and other interested people should be the first step taken in getting a new program under way. This committee can aid in placing graduates, recruiting new students, recommending curriculum needs and revisions, and interpreting the program to the public.

Again I would like to say that we consider the library-media technical assistant as an essential team member of the media-center staff; she may be responsible for the supervision of other technicians, clerks, or media aides in addition to her other duties. Graduates of the program all over United States and Canada have found employment in community colleges and technical institutes, public schools, academic, special libraries, instructional-material centers, learning laboratories, and reading centers. Beginning salaries for the library-media technical assistant may range from $\$ 4,800$ to $\$ 6,000$, depending on the location and the position. The opportunities for finding employment are greater where an institution offering a library-media technical assistant program serves an area of 100,000 or more population. The success of any program depends on whether or not it satisfactorily meets the community's needs.

I would like to introduce you now to a "typical," composite picture if there is such a thing, of a LMTA graduate. This person is female and quite attractive, with a great sense of humor. She is poised, intelligent, and curious concerning the world around her. Being oriented to the world of work, she is very practical and realistic in her daily life, and relates well to others who come to her for assistance. Her average age is about 24 years. She is married and has one child, weighs
130 lbs. more or less, and has graduated from high school when she enters Caldwell Community College.

Because most of these girls are interested in immediate employment, they come to us looking for two-year training that will lead them in that direction. The majority of them have average to above average I.Q. and prove to be diligent students. By the second year, those who are still with us have made a great deal of progress. They have developed a confidence and self awareness which enables them to adapt or fit into a number of situations. They are extremely proud of their jobs and take a great deal of interest in keeping things going smoothly. They see things to do and can be depended upon to carry a project through to com. pletion.

In retrospect, one unusual fact stands out - there is the large percentage of these young women who graduate with honors every year (this spring there were 5 girls out of 12). Our classes are small and it is hoped that they will continue to be. Almost all the girls have found employment, even though there are four who have preferred staying in the Lenoir ared to leaving for greener pastures. They have found employment, however.

You will remember that I mentioned that our program is based on a broad curriculum which enables the graduate to adapt to different situations in which they might find themselves. I would like to name a few cases: two of our girls are working in the audio-visual areas of two community colleges learning resources cen" ters. One is keeping the books and records in a public library, (she feels that her accounting has been most valuable to her.) and one young woman is key punching for the computer catalog. The central process ing center for Burlington City Schools has been well-pleased with the services of one of our graduates. Our handicapped 
girl supervises the work study students in her situation and keeps the circulation desk going; another technical assistant, who has charge of Inter-library loans, finds that she must be familiar with IN-WATS service and bibliographic tools. LenoirRhyne has one of our girls on the staff in Hickory and Western Carolina Center has a technician also in the center.

Changes have occurred in the curriculum as needs were recognized. I met with the State Advisory Committee several times last year whose purpose was to evaluate all the programs in the state and to make suggestions as to needed changes. We discussed the importance of controlling the numbers of new programs since there would be a saturation point for employment.

The opportunities, as I see them, for employment lie in many directions, since the LMTA training prepares a very versafile employee. There are the traditional academic libraries, the learning resources centers of the community colleges, the media centers (or school libraries), and special libraries in each service area. Central processing centers, learning laboratories with programmed instruction, reading centers, and film centers all require the skills for which a LMTA has training. There have been more requests from community colleges and universities for this trained library assistant than could be filled, however the local market is limited for such positions. The administration at the state level does not include this position in the salary scale set up for public school personnel.

In our discussion, I would like to say that some time ago I mentioned COLT (Council on Library Technology). This is an organization which has studied, evaluated, and promoted the LTA program for the last six years through workshops and conferences. It has given encouragement and direction to many new and struggling programs. Major problems which the council has studied and with which it will continue to deal include: the development of clear job description, criteria for employment of technicians, studies of placement opportunities and salary structure, coordination of course sequences and curricula content among the various programs, cooperation with the American Library Association in establishment of guidelines, and the dissemination of information to the public and to prospective students.

\section{Broadfoot's} Bookmark

\author{
Books \& Art
}

North Carolina Books - 100 pg. catalog ready - send for free copy. Discount to N. C. libraries on new N.C. titles. Buy out-ofprint volumes in quantity and save up to $75 \% .40,000$ volumes to choose from. Titles shelved alphabetically by subject area in large new bookstore.

10 miles East of Raleigh on U.S. 64

Mon.-Sat. 10-5

(919) $365-6963$ 